\title{
Serological Studies of Bacteroides gracilis, Campylobacter concisus, Wolinella recta, and Eikenella corrodens, All from Humans with Periodontal Disease
}

\author{
SHIRLEY J. BADGER ${ }^{1}$ AND ANNE C. R. TANNER ${ }^{2}$ \\ Department of Microbiology, School of Medicine, Case Western Reserve University, Cleveland, Ohio 44106 \\ and Forsyth Dental Center, Boston, Massachusetts $02115^{2}$
}

\begin{abstract}
Gram-negative, asaccharolytic, agar-corroding organisms were isolated from lesions of advanced destructive periodontal disease. We grouped 78 oral isolates and reference strains of Eikenella corrodens, Bacteroides ureolyticus, Wolinella succinogenes (Vibrio succinogenes), and Campylobacter spp. serologically by using the microagglutination technique. The four species of oral organisms $(E$. corrodens, Bacteroides gracilis, Wolinella recta, and Campylobacter concisus) were clearly differentiated from each other on the basis of agglutination with rabbit antisera produced against representative live organisms. Agglutination patterns showed both a lack of intergroup relatedness among the oral isolates and a lack of serological identity with the biochemically similar organisms $W$. succinogenes, B. ureolyticus, and Campylobacter species.
\end{abstract}

The involvement of microorganisms in the destruction of periodontal tissues has been well established (1-4, 7, 8). Gram-negative, anaerobic bacteria are predominant in the deep pockets of periodontitis $(6,10)$. The identification of these gram-negative organisms is an obligatory first step toward an understanding of their role in disease.

Asaccharolytic, gram-negative, rod-shaped bacteria that caused pitting or corrosion of the surface of blood agar plates were isolated from lesions in humans with advanced destructive periodontal disease by Tanner et al. (10). In some lesions these bacteria were numerically dominant. Such organisms most closely resembled Eikenella corrodens, Bacteroides ureolyticus, Vibrio succinogenes, and Campylobacter sputorum. Reference strains of these four species and 46 oral isolates were studied on the basis of their phenotypic characteristics and the guanine-plus-cytosine contents of their deoxyribonucleic acids (DNAs) and by DNA-DNA hybridization (9). One group of organisms was taxonomically similar to the type strain of $E$. corrodens, and the strains in this group were identified as members of $E$. corrodens. The remaining isolates did not fit existing species descriptions and were thus assigned to newly named species. The nonmotile anaerobic agar corroders were placed in the species Bacteroides gracilis. The motile anaerobic rod-shaped organisms had biochemical characteristics and guanine-pluscytosine contents (42 to $46 \mathrm{~mol} \%$ ) similar to those of $V$. succinogenes as described by Wolin et al. (11); therefore, $V$. succinogenes Wolin et al. 1961 was transferred to a new genus, Wolinella, and the anaerobic, motile, rod-shaped bacteria that corroded agar were named Wolinella recta. Motile, microaerophilic organisms which had guanine-plus-cytosine contents of 34 to 38 $\mathrm{mol} \%$ differed from reference Campylobacter strains and were named Campylobacter concisus.

In this paper we describe serogrouping by microagglutination of the organisms studied by Tanner et al. (9) and additional strains which were isolated at Case Western Reserve University.

\section{MATERIALS AND METHODS}

Bacterial strains. The isolates from humans with periodontal lesions were purified and characterized as described by Tanner et al. (9). The nine strains from the Case Western Reserve Dental Clinic were isolated from lesions in humans with advanced periodontitis, and they were identified with a B preceding the strain number. Strain numbers with the suffix $R$ indicate the raised, noncorroding colony type. The reference strains of $E$. corrodens used were ATCC 23834, 597, 598, and MG-7905; the last strain was isolated from a human bite wound by M. Wolinsky, Cleveland Metropolitan General Hospital. Details concerning the sources of the strains from the Forsyth Dental Center and their identification are described by Tanner et al. (9). In addition, strains $375,444 \mathrm{~A}, 461,462,463,465$, $477 \mathrm{R}, 480,525$, and 530 were isolated from lesions in humans with periodontitis, strains 558, 569R, and 1076 were isolated from pockets associated with gingivitis, and strain 1085 was isolated from a human with a periodontosis lesion. 
Media for growth of live vaccines and agglutination antigens. Medium CS3 was used to grow $E$. corrodens; this medium contained (per liter) $17 \mathrm{~g}$ of Trypticase (BBL Microbiology Systems, Cockeysville, Md.), $3 \mathrm{~g}$ of Phytone (BBL), $2 \mathrm{~g}$ of potassium nitrate, $1 \mathrm{~g}$ of sodium formate, and $3 \mathrm{mg}$ of hemin. The first four ingredients were dissolved in distilled water at a fivefold concentration, and this preparation was vacuum dialyzed to remove potentially antigenic substances present in the high-molecular-weight fraction. After the effusate was diluted and autoclaved, $1 \mathrm{ml}$ of a sterile solution of $0.3 \%$ hemin in $1 \mathrm{M}$ sodium carbonate and $10 \mathrm{ml}$ of filter-sterilized $1 \mathrm{M}$ potassium bicarbonate were added aseptically.

The supplemented Todd-Hewitt broth used to grow Wolinella, Campylobacter, and Bacteroides strains contained $2 \mathrm{~g}$ of potassium formate per liter, $3 \mathrm{~g}$ of potassium fumarate per liter, and $3 \mathrm{mg}$ of hemin per liter, which were added as described above.

Antigen preparation. Single colonies were streaked onto sheep blood agar plates, which were incubated under $80 \% \quad \mathrm{~N}_{2}-10 \% \mathrm{CO}_{2}-10 \% \mathrm{H}_{2}$ in a gas evacuation replacement jar with a palladium catalyst; 10 to 20 colonies were removed from each plate with a Pasteur pipette and inoculated into $10 \mathrm{ml}$ of dialyzed medium CS3 or supplemented Todd-Hewitt broth. After $24 \mathrm{~h}$ of anaerobic incubation, $5 \mathrm{ml}$ of each culture was used to inoculate $100 \mathrm{ml}$ of broth. After $24 \mathrm{~h}$, the cells were harvested by centrifugation at $12,000 \times g$ for $10 \mathrm{~min}$ and then washed once with $10 \mathrm{ml}$ of phosphate-buffered saline ( $\mathrm{pH} 7.2$ ) (if they were used for agglutination tests), or twice with phosphatebuffered saline (if they were used for vaccines).

For agglutination tests, the cell paste was suspended in phosphate-buffered saline at an optical density at $540 \mathrm{~nm}$ of 1.2 , or it was matched to a McFarland no. 9 standard. Cells were suspended in phosphatebuffered saline at a concentration of $2 \times 10^{9}$ cells per $\mathrm{ml}$ (optical density at $540 \mathrm{~nm}, 0.82$ ) for vaccines.

Antiserum production in rabbits. Two regimens were used. Anti-Eikenella sera were produced in New Zealand white rabbits ( 5 to $6 \mathrm{lb}$ [ 2.27 to $2.72 \mathrm{~kg}$ ]) by injecting them intravenously with $10^{9}$ live organisms in $1.0 \mathrm{ml}$ of phosphate-buffered saline. The rabbits were injected every other day with $1.5 \times 10^{9}, 3 \times 10^{9}$, and $5 \times 10^{9}$ cells for a total of four injections, bled after 17 to 21 days, rested for 1 week, injected with 5 $\times 10^{9}$ live cells, and sacrificed 5 days later by exsanguination from the heart.

Antisera were prepared against the remaining strains by injecting rabbits subcutaneously at four sites with $1 \times 10^{9}$ to $4 \times 10^{9}$ live bacterial cells which had been dispersed by mixing in incomplete Freund adjuvant. Injections were repeated at 1 -week intervals for a total of four injections. The rabbits were exsanguinated by cardiac puncture 1 week after the last vaccination.

Sera were sterilized by filtration, dispensed in 1-ml volumes into sterile plastic tubes ( 12 by $75 \mathrm{~mm}$ ), and frozen at $-70^{\circ} \mathrm{C}$. Working tubes of sera were thawed rapidly and stored at $4^{\circ} \mathrm{C}$ in $1 \mathrm{mM}$ sodium azide.

Microagglutination test procedure. Initially, all sera were diluted 1:10. A total of 12 twofold serial dilutions were made in phosphate-buffered saline con- taining $5 \%$ sucrose by using microtiter plates and 0.025-ml diluters (Dynatech Laboratories, Inc., Alexandria, Va.). The addition of sucrose prevented autoagglutination of the whole-cell antigen preparation. One drop $(0.025 \mathrm{ml})$ of bacterial suspension (optical density at $540 \mathrm{~nm}, 1.2$ ) was added to each well. Control wells contained diluted preimmune serum. The plates were rocked for $10 \mathrm{~min}$ on a platform shaker (Eberbach and Son Co., Ann Arbor, Mich.) which moved $5 \mathrm{~cm}$ at 120 oscillations per min; then they were incubated at $37^{\circ} \mathrm{C}$ for $20 \mathrm{~min}$ and read under a dissecting microscope. Positive agglutination patterns varied from perceptible small granules to large floccules which settled quickly into a pellet. Homologous titers and duplicate samples were within one dilution of the expected titer.

\section{RESULTS}

The four species of oral strains could be distinguished serologically, since microagglutination between strains of different species did not occur.

Antisera were prepared against $E$. corrodens strains $1073,530,479$, and 373 from patients with periodontitis and two reference strains, strains ATCC 23834 and 598. All of these immunizing strains except strain 479 were of the corrodingspreading colony type. Table 1 shows the microagglutination titers of these antisera with 50 isolates of $E$. corrodens. Many strains displayed multiple antigens and cross-reactivity, as has been reported by Schroter (5) for clinical isolates of $E$. corrodens. The strains were grouped according to the serum or sera with which the highest agglutination titer was observed. Strains that were most similar to strain 1073 were placed in group A (Table 1). The organisms in group A1 were also identified by anti-1073 serum, but in addition they contained antigens in common with reference strains ATCC 23834 and 598. Strains in group A-1 were agglutinated by anti1073 serum at titers which were greater than or equal to the titers obtained when anti-ATCC 23834 serum was used; this was in contrast to group B strains, which all showed lower titers when they were tested with anti-1073 serum than when they were tested with anti-ATCC 23834 serum. Strains in groups B and C most closely resembled the reference strains ATCC 23834 and 598, respectively. Approximately $60 \%$ of the strains could be identified as $E$. corrodens by the antiserum to strain 1073. Groups E and $F$ had unique antigenic determinants and showed little cross-reactivity with other strains.

Table 2 shows the serological relationships among strains of $W$. recta. Antisera were prepared against strains 285 and 371 and the atypical strain 286. $W$. recta isolates formed two serogroups which showed no cross-reactions with strains of $C$. concisus, $E$. corrodens, and $B$. 
TABLE 1. Groupings of $E$. corrodens strains as determined by microagglutination titer tests

\begin{tabular}{|c|c|c|c|c|c|c|c|}
\hline \multirow[b]{2}{*}{ Group } & \multirow{2}{*}{$\begin{array}{l}\text { Strain that was the } \\
\text { source of whole-cell } \\
\text { antigen }^{\alpha}\end{array}$} & \multicolumn{6}{|c|}{ Titer with antiserum from: ${ }^{b}$} \\
\hline & & Strain 1073 & $\begin{array}{c}\text { Strain } \\
\text { ATCC } \\
23834\end{array}$ & Strain 598 & Strain 530 & Strain 373 & $\begin{array}{c}\text { Strain } \\
479 R\end{array}$ \\
\hline \multirow[t]{12}{*}{ A } & 1073 & $10,240^{c}$ & 160 & 320 & 640 & 80 & $-{ }^{d}$ \\
\hline & 1073R & 5,120 & 640 & 640 & 1,280 & 40 & - \\
\hline & 1079 & 10,240 & 640 & 640 & 320 & 80 & 80 \\
\hline & $1079 \mathrm{R}$ & 10,240 & 320 & 640 & 640 & 80 & 80 \\
\hline & 1085 & 5,120 & 320 & 320 & 640 & 80 & - \\
\hline & B-122 & 5,120 & 640 & 640 & 320 & 320 & 80 \\
\hline & 558 & 1,280 & 160 & - & 160 & - & 80 \\
\hline & $558 \mathrm{R}$ & 1,280 & 80 & - & 80 & - & 160 \\
\hline & $1008 \mathrm{R}$ & 1,280 & 80 & - & 80 & - & 80 \\
\hline & $1006 \mathrm{R}$ & 1,280 & 80 & - & 80 & - & 80 \\
\hline & 464 & 1,280 & 640 & 160 & 160 & 640 & 160 \\
\hline & 1081 & 1,280 & 40 & - & 80 & - & 80 \\
\hline \multirow[t]{8}{*}{ A-1 } & 525 & 2,560 & 640 & 2,560 & 640 & 80 & - \\
\hline & B-120 & 2,560 & 640 & 2,560 & 640 & 40 & - \\
\hline & B-126 & 2,560 & 160 & 2,560 & 320 & - & 80 \\
\hline & MG-7905 & 5,120 & 1,280 & 5,120 & 1,280 & 640 & 160 \\
\hline & 1009 & 5,120 & 5,120 & 640 & 640 & 160 & 80 \\
\hline & $1009 \mathrm{R}$ & 2,560 & 160 & 320 & 320 & - & - \\
\hline & 1010 & 2,560 & 2,560 & 640 & 320 & - & - \\
\hline & 467 & 1,280 & 1,280 & 640 & 80 & 320 & - \\
\hline \multirow[t]{3}{*}{ B } & ATCC 23834 & 1,280 & $5,120^{c}$ & 1,280 & 640 & 160 & 40 \\
\hline & B- 121 & 160 & 2,560 & 320 & 320 & - & - \\
\hline & $569 \mathrm{R}$ & 160 & 640 & 320 & 160 & 80 & 40 \\
\hline \multirow[t]{7}{*}{$\mathrm{C}$} & 598 & 160 & 320 & $10,240^{c}$ & 320 & 160 & 160 \\
\hline & 597 & 160 & 640 & 1,280 & 320 & 80 & 80 \\
\hline & 1078 & 1,280 & 320 & 5,120 & 320 & 80 & 160 \\
\hline & $1078 \mathrm{R}$ & 1,280 & 320 & 1,280 & 320 & 80 & 80 \\
\hline & B-124 & 320 & 320 & 1,280 & 160 & - & - \\
\hline & $477 \mathrm{R}$ & 320 & 40 & 1,280 & 640 & 160 & 40 \\
\hline & 469 & - & 320 & 640 & 80 & 320 & - \\
\hline D & 530 & 2,560 & 160 & 640 & $10,240^{c}$ & 40 & - \\
\hline \multirow[t]{11}{*}{$\mathrm{E}$} & 373 & 80 & 40 & 160 & 40 & $5,120^{c}$ & 80 \\
\hline & 374 & 80 & 160 & - & - & 5,120 & 80 \\
\hline & 1075 & - & 40 & - & - & 5,120 & - \\
\hline & 1075R & - & - & - & - & 2,560 & - \\
\hline & 384 & 80 & 160 & 160 & - & 5,120 & - \\
\hline & 1074 & 40 & - & - & - & 2,560 & - \\
\hline & 1076 & - & 320 & 80 & 80 & 2,560 & 80 \\
\hline & $1076 \mathrm{R}$ & - & 40 & 80 & - & 80 & 320 \\
\hline & 375 & 160 & 40 & - & - & 2,560 & - \\
\hline & 470 & 80 & 80 & 80 & 80 & 640 & - \\
\hline & $470 \mathrm{R}$ & - & - & 40 & - & 1,280 & 40 \\
\hline \multirow[t]{10}{*}{$\mathbf{F}$} & $479 \mathrm{R}$ & - & 80 & 160 & - & - & $2,560^{c}$ \\
\hline & $444 \mathrm{~A}$ & - & 80 & 40 & - & - & 1,280 \\
\hline & 461 & - & 160 & 40 & - & 160 & 1,280 \\
\hline & 462 & - & 80 & 80 & - & - & 640 \\
\hline & 463 & - & 80 & 80 & - & 40 & 1,280 \\
\hline & 465 & - & 80 & 40 & - & - & 640 \\
\hline & 466 & - & - & 160 & - & - & 640 \\
\hline & 480 & - & 80 & 40 & - & 80 & 640 \\
\hline & 468 & - & 80 & 80 & - & - & 320 \\
\hline & 469R & - & - & 80 & - & 40 & 640 \\
\hline
\end{tabular}

${ }^{a}$ The suffix $\mathrm{R}$ indicates raised, noncorroding colony types.

${ }^{b}$ Titer is expressed as the reciprocal of the highest serum dilution that caused agglutination.

${ }^{c}$ Homologous titer.

${ }^{d}$ - No agglutination detected.

${ }^{e}$ Strain MG-7905 is a hospital isolate from a human bite wound. 
gracilis or with strain VPI 9584. Strain 286 showed high homologous titers but low crossreactivities with some $W$. recta isolates.

Table 3 shows the microagglutination titers of $B$. gracilis strains. These isolates formed a single serogroup which showed no cross-reactivity with isolates in any of the other groups. Antiserum to strain 1084 did not react with $B$. ureolyticus strain 7815 .

The microagglutination titers of the $C$. concisus strains tested are shown in Table 4 . These organisms showed no cross-reactivity with any other reference strain tested, including $C$. sputorum and Campylobacter fetus. With the ex- ception of strain 288 , these strains formed one serological group.

\section{DISCUSSION}

$E$. corrodens, B. gracilis, W. recta, and $C$. concisus can be differentiated from each other serologically by agglutination (Tables 2 through 4) or by immunofluorescent staining (Badger, unpublished data).

We observed two serogroups of W. recta. Strain 286, which represented a third serogroup, showed a Jaccard similarity coefficient of $80 \%$ and a similarity as determined by DNA hybridization of $50 \%$ with respect to $W$. recta strains

TABLE 2. Serological reactions of oral strains of W. recta

\begin{tabular}{|c|c|c|c|c|c|c|c|}
\hline \multirow{2}{*}{$\begin{array}{l}\text { Strain that was the } \\
\text { source of whole-cell } \\
\text { antigen }\end{array}$} & \multirow{2}{*}{$\begin{array}{l}\text { Guanine-plus- } \\
\text { cytosine con- } \\
\text { tent of DNA } \\
(\mathrm{mol} \%)\end{array}$} & \multicolumn{6}{|c|}{ Titer with antiserum from: ${ }^{a}$} \\
\hline & & Strain 285 & Strain 371 & Strain 286 & $\begin{array}{l}\text { C. conci- } \\
\text { sus } 484\end{array}$ & $\begin{array}{c}\text { B. gra- } \\
\text { cilis } 1084\end{array}$ & $\begin{array}{l}\text { E. corro- } \\
\text { dens } 1073\end{array}$ \\
\hline \multicolumn{8}{|l|}{ W. recta } \\
\hline 285 & 42 & $640^{b}$ & 40 & $-^{c}$ & - & - & - \\
\hline $1082 \mathrm{~V}$ & 45 & 320 & 40 & - & - & - & - \\
\hline $285 R$ & 42 & 320 & 40 & - & - & - & - \\
\hline 267 & 43 & 640 & 40 & - & - & - & - \\
\hline B-16 & & 320 & - & 80 & - & - & - \\
\hline B- 8 & & 320 & 80 & 40 & - & - & - \\
\hline 371 & 43 & 80 & $320^{b}$ & - & - & - & - \\
\hline 603 & & 80 & 320 & - & - & - & - \\
\hline 302 & 43 & - & 320 & - & - & - & - \\
\hline $302 \mathrm{R}$ & 43 & - & 320 & - & - & - & - \\
\hline B-136 & & - & 320 & - & - & - & - \\
\hline 372 & 43 & - & 160 & 40 & - & - & - \\
\hline 303 & 45 & - & 160 & - & - & - & - \\
\hline 557 & & - & 160 & - & - & - & - \\
\hline B-98 & & - & 160 & - & - & - & - \\
\hline 286 & 45 & - & - & $1,280^{b}$ & - & - & - \\
\hline VPI 9584 & 46 & - & - & - & - & - & - \\
\hline
\end{tabular}

${ }^{a}$ Titer is expressed as the reciprocal of the highest antiserum dilution that caused agglutination.

${ }^{b}$ Homologous titer.

c - No agglutination detected.

TABLE 3. Serological reactions of $B$. gracilis strains

\begin{tabular}{|c|c|c|c|c|c|c|}
\hline \multirow{2}{*}{$\begin{array}{l}\text { Strain that was the source of whole-cell } \\
\text { antigen }\end{array}$} & \multirow{2}{*}{$\begin{array}{l}\text { Guanine- } \\
\text { plus-cytosine } \\
\text { content of } \\
\text { DNA (mol\%) }\end{array}$} & \multicolumn{5}{|c|}{ Titer with antiserum from: ${ }^{a}$} \\
\hline & & Strain 1084 & $\begin{array}{l}\text { W. recta } \\
285\end{array}$ & $\begin{array}{l}\text { W. recta } \\
371\end{array}$ & $\begin{array}{l}\text { C. conci- } \\
\text { sus } 484\end{array}$ & $\begin{array}{l}\text { E. corro- } \\
\text { dens } 1073\end{array}$ \\
\hline \multicolumn{7}{|l|}{ B. gracilis } \\
\hline 1084 & 45 & $640^{b}$ & $-c$ & - & - & - \\
\hline 1083 & 45 & 320 & - & - & - & - \\
\hline 1082 & 45 & 160 & - & - & - & - \\
\hline 401 & 45 & 640 & - & - & - & - \\
\hline $401 \mathrm{R}$ & 45 & 640 & - & - & - & - \\
\hline 402 & 46 & 640 & - & - & - & 一 \\
\hline 406 & 46 & 320 & - & - & - & - \\
\hline B. ureolyticus VPI 7815 & 28 & - & - & - & - & - \\
\hline
\end{tabular}

${ }^{a}$ Titer is expressed as the reciprocal of the highest dilution of antiserum that caused agglutination.

${ }^{b}$ Homologous titer.

c - , No agglutination detected. 
TABLE 4. Serological reactions of C. concisus isolates

\begin{tabular}{|c|c|c|c|c|c|c|c|}
\hline \multirow[b]{2}{*}{$\begin{array}{c}\text { Strain that was the source of whole-cell } \\
\text { antigen }\end{array}$} & \multirow{2}{*}{$\begin{array}{l}\text { Guanine- } \\
\text { plus-cy- } \\
\text { tosine } \\
\text { content } \\
\text { of DNA } \\
\text { (mol\%) }\end{array}$} & \multicolumn{6}{|c|}{ Titer with antiserum from: } \\
\hline & & Strain 484 & $\begin{array}{l}\text { W. recta } \\
285\end{array}$ & $\begin{array}{l}\text { W. recta } \\
371\end{array}$ & $\begin{array}{l}\text { W. recta } \\
286\end{array}$ & $\begin{array}{c}\text { B. gra } \\
\text { cilis } \\
1084\end{array}$ & $\begin{array}{c}\text { E. cor } \\
\text { rodens } \\
1073\end{array}$ \\
\hline \multicolumn{8}{|l|}{ C. concisus } \\
\hline 484 & 38 & $1,280^{a}$ & $一^{b}$ & - & - & - & - \\
\hline 483 & 37 & 640 & - & - & - & - & - \\
\hline 522 & 38 & 320 & - & - & - & - & - \\
\hline 569 & 38 & 320 & - & - & - & - & 一 \\
\hline 485 & 36 & 320 & - & - & - & - & - \\
\hline 288 & 38 & - & - & - & 640 & - & 一 \\
\hline \multicolumn{8}{|l|}{ Reference Campylobacter strains } \\
\hline C. sputorum VPI S17 & 30 & - & - & - & - & - & 一 \\
\hline C. fetus VPI 1176 & 31 & - & - & - & - & - & 一 \\
\hline
\end{tabular}

${ }^{a}$ Homologous titer.

${ }^{b}-$, No agglutination detected.

(9). A similar strain, which was isolated from a root canal, has been reported recently; this strain was homologous with strain 286 (R. A. Visconti, A. C. R. Tanner, L. V. Holdeman, G. Sundqvist, and S. S. Socransky, J. Dent. Res. 58A:105, abstr. 976, 1979), and this information suggests that these two organisms represent another Wolinella species.

With the exception of strain 288 , the motile microaerophilic organisms used in this study were a serologically distinct group. Strain 288 appeared to have an antigen in common with strain 286 .

The $B$. gracilis strains formed a single serogroup. The relatively small number of strains examined may have precluded the observation of other serovars (serotypes).

$E$. corrodens strains were antigenically diverse, with many of the isolates showing strong cross-reactions. Coykendall and Kaczmarek found that strains of $E$. corrodens, including many isolates tested in this investigation, represented a single DNA homology group (A. L. Coykendall and F. S. Kaczmarek, J. Dent. Res. 59A:512, abstr. 971, 1980), so the serological heterogeneity of these organisms apparently does not indicate the presence of more than one species. Antiserum to strain 1073 reacted with $60 \%$ of the isolates. This strain seemed to be more typical of oral $E$. corrodens isolates than the reference strains ATCC 23834 and 598 did. Two serogroups of $E$. corrodens, groups $\mathrm{E}$ and F (Table 1), corresponded closely to clusters defined by an analysis of phenotypic features (9), and each appeared to display one predominant antigen. The antisera which reacted with strains in serogroups $E$ and $F$ were prepared against strains 373 and 479 , respectively. Both of these strains were isolated from patients with rapidly progressive periodontal disease. No strains belonging to serogroups $\mathrm{E}$ and $\mathrm{F}$ were found among 40 isolates of $E$. corrodens from the healthy gingiva of young adults, suggesting that some serovars of $E$. corrodens are more pathogenic than others (S. Badger and J. Peterson, J. Dent. Res. 57 A:315, abstr. 962, 1978).

\section{ACKNOWLEDGMENTS}

This investigation was supported by Public Health Service grant DE-04422 from the National Institute of Dental Research.

We thank Judith $\mathrm{H}$. Weiss for technical assistance

\section{REPRINT REQUESTS}

Address reprint requests to: Dr. Shirley J. Badger, Department of Microbiology, School of Medicine, Case Western Reserve University, Cleveland, $\mathrm{OH} 44106$.

\section{LITERATURE CITED}

1. Bahn, A. N. 1970. Microbial potential in the etiology of periodontal disease. J. Periodontol. 41:603-610.

2. Ellison, S. A. 1970. Oral bacteria and periodontal disease. J. Dent. Res. 49:198-202.

3. Genco, R. J., R. T. Evans, and S. A. Ellison. 1969 Dental research in microbiology with emphasis on periodontal disease. J. Am. Dent. Assoc. 78:1016-1036.

4. Kelstrup, J., and E. Theilade. 1974. Microbes and periodontal disease. J. Clin. Periodontol. 1:15-35.

5. Schroter, G. 1974. Studies on the antigenic structure of Eikenella corrodens. Ann. Microbiol. (Paris) 125B:5974.

6. Slots, J. 1977. The predominant cultivable microflora of advanced periodontitis. Scand. J. Dent. Res. 85:114.

7. Socransky, S. S. 1970 . Relationship of bacteria to the etiology of periodontal disease. J. Dent. Res. 49:203222.

8. Socransky, S. S. 1977. Microbiology of periodontal disease. Present status and future considerations. J. Periodontol. 48:497-504.

9. Tanner, A. C. R., S. Badger, C.-H. Lai, M. A. Listgarten, R. A. Visconti, and S. S. Socransky. 1981 Wolinella gen. nov., Wolinella succinogenes (Vibrio 
succinogenes Wolin et al.) comb. nov., and description of Bacteroides gracilis sp. nov., Wolinella recta sp. nov., Campylobacter concisus sp. nov., and Eikenella corrodens from humans with periodontal disease. Int. J. Syst. Bacteriol. 31:432-445.

10. Tanner, A. C. R., C. Haffer, G. T. Bratthall, R. A.
Visconti, and S. S. Socransky. 1979. A study of the bacteria associated with advancing periodontitis in man. J. Clin. Periodontol. 6:278-307.

11. Wolin, M. J., E. A. Wolin, and N. J. Jacobs. 1961. Cytochrome-producing anaerobic vibrio, Vibrio succinogenes sp. n. J. Bacteriol. 81:911-917. 